\title{
ON SOME NON-CONVENTIONALIZED USES OF THE TRANSITIVE CONSTRUCTION IN POLISH
}

\author{
KINGA RUDNICKA-SZOZDA
}

\section{Introduction}

The present study ${ }^{1}$ is aimed to present a selection of Polish data which illustrate the speaker's dexterity with manipulating the well conventionalized transitive construction in order to achieve some semantico-pragmatic and rhetorical effects. The basic goal is to account for selected data that constitute highly marginal and/or novel instances of the transitive coding in Polish. In doing so, the main focus is put on the conceptual import of the transitive construction. It is argued that this type of linguistic evidence should not be ignored in linguistic analyses but rather ought to be seen as a visible manifestation of the speakers' ability and also need to apply linguistic structures creatively. The motivation behind the choice of this kind of research data goes along the following observation made by Nishimura:

(...) human beings must make creative use of the limited conceptualizing devices with which they are equipped by their languages and other cognitive systems in order to structure and understand ever increasing novel situations, either actual or hypothetical. Consequently, semantic structures must now and again be applied to situations for which they were not originally meant (i.e. non-paradigm situations)

(Nishimura, 1993: 495)

Consequently, the study investigates some creative uses of the clausal structure involving transitivity, e.g. the use of an inherently intransitive verb with direct ob-

\footnotetext{
${ }^{1}$ The study is based on the author's unpublished doctoral dissertation (Rudnicka, 2009).
} 
ject. Since the study is primarily concerned with the transitive category, some departures from the transitivity prototype will be analysed and the motivation behind the instances of highly non-canonical coding in Polish will be sought. It is believed that the analysis of this type of data acquires special value within the framework of cognitive linguistics where it is perceived as evidence supporting the fundamental claim that grammatical constructs are meaningful. This view of linguistic structure sheds new light on transitivity as it provides the necessary tools that allow for the analysis of various non-prototypically transitive clauses, as is argued by Rice:

If we view transitivity as a continuum describing dynamic action that gets overlaid conceptually on a range of sentence types, we can begin to make sense of some of these disparate phenomena that allow a particular objective scene to be variably construed towards or away from canonical transitivity

(Rice, 1987: 244)

It will be claimed that the examples serve as clear evidence supporting this claim.

\section{The transitive construction}

Rice (1987) characterizes the transitive event in relation to Langacker's canonical event model (1991). She considers transitivity, in its conceptual sense, to be a property of situations that prototypically portray a particular type of interaction between two participants. A transitive event can be described in relation to the following notions: asymmetry, contact, dicretedness, effect, distinctiveness. Specifically, two cognitively salient and highly individuated participants are involved in a unitary, completed, dynamic action, as in the example in the English example in (1a) and the Polish example in 1(b). In Polish the agent is overtly marked with the nominative case and the direct object is marked with the accusative case.

(1)

(a) John broke the vase.

(b) Jan: NOM sttukt wazon: ACC

The entity onto which the operation is directed, i.e. the vase, is directly affected as a consequence of the agent's performance and gets broken. Consequently, transitivity is to be understood relative to the observed interaction of physical entities in the real world. Prototypically, a transitivie clause encodes an event approximating the canonical event model. However, transitivity prototype(s) and transitivity components may be realized neither lexically nor syntactically, which leads to a conclusion that they are closely connected to the interpretation of both the predicate and the predication. 


\section{Introducing the causer}

The first type of the unconventionalized uses of the transitive coding involves the manipulation with regard to the entity performing the action. Consider the example in (2), in which a prototypically intransitive verb is employed in the transitive construction.

(2) Jak wieś ma dwa domy to tatwo zniknać ją $z$

if village has two houses it easy disappear it: ACC from

'If a village has two houses it is easy to disappear it from

powierzchni ziemi.

surface: GEN earth: GEN

the earth's surface.'

(3) Jak wieś ma dwa domy to łatwo sprawić, żeby zniknęła z

if village has two houses it easy make to disappear from

'If a village has two houses it is easy to make it disappear from

powierzchni ziemi.

surface: GEN earth: GEN

the earth's surface.'

(4) Jak wieś ma dwa domy to tatwo znika z

if village has two houses it easy disappear-pres- $3^{\text {rd }} \mathrm{sg}$ from

'If a village has two houses it easily disappears from

powierzchni ziemi.

surface: GEN earth: GEN

the earth's surface.'

In its prototypical use, the verb znikać ('disappear') is intransitive and characterizes an action involving an internally caused change as is shown in (4), where the change comes naturally in an entity due to its inherent properties. However, in (2) the event is construed as if it were caused by some external causer that is assigned the responsibility for the change. Thus, the construals in (2) and (4) differ primarily with regard to the responsibility taken for the action and its results. According to Smith, the difference between internal and external responsibility for the events described by change-of-state verbs involves the difference in control, i.e. an externally controlled event is characterized by the agent taking external control of the change (see Smith, 1970: 101, discussed in McKoon and Macfarland, 2000). On the other hand, internally caused change-of-state verbs denote states that occur naturally in an entity as their source is internal to the entity that changes state. In contrast to the clauses in (2) and (4), the overtly causative construction in (3), though semantically close to (2), produces a less immediate interpretation of the event as it separates the lexemes denoting the input of energy, i.e. sprawic ('make'), from those refering to the process instigated, i.e. zniknęla ('disappear). As compared to (2), 
the clause in (3) reflects iconically that a greater distance between the lexical items involves a less direct relationship between the entities they denote.

The conceptual structure underlying examples such as (2) can be characterized in terms of the expansion of the profile. Langacker (1991) observes that an intransitive verb can be employed with a causative predication, by means of which the profiled one-participant relationship is expanded into a two-participant event. The schema given below represents the change (Langacker, 1991: 256).

\section{$[\mathrm{A}>]$ changes to $[\mathrm{B} \rightarrow[\mathrm{A}>]]$}

According to Langacker, participant $\mathrm{B}$, which functions as the action-chain head, is selected as the subject. On the other hand, entity A, which undergoes a change of state and is the tail of the action chain, is chosen as a direct object and receives the appropriate case marking. In Polish it is marked by the accusative case.

Consider now the example in (5). In the non-conventionalized transitive constructions with prototypically intransitive verbs introducing a causer, the verb usually denotes an action that normally cannot be instigated by an external causer. Either it fails to be lexicalized, e.g. the novel use of the verb zniknać ('disappear') has no other conventionalized lexeme, or simply because causing the change is generally thought to be impossible. The latter situation is illustrated in (5) below.

(5) Wobec braku jakichkolwiek sukcesów przy indolencji

ministrów ocierającej się o sabotaż albo kretynizm (...),

trzeba na gwalt zanotować „,cós”. Co? Ano można

np. ,, zachorować" pilota żeby Prezydent nie miat czym lecieć.

Dobrze, że tylko „zachorować”, bo można byłoby go ,zniknąc’”... Jak Orwell, to Orwell.

'In face of the lack of any success and the indolence of the ministers close to sabotage or cretinism (...), you urgently need to note "something". What? Well, you can, e.g. "fall-ill" a pilot: ACC so that the President had nothing to fly with. Fine, if you only "fall-ill" him, as you could also "disappear" him: ACC... Orwell is Orwell'

In the normal course of events one cannot make another person fall sick, hence, there exists no Polish verb that conventionally lexicalizes this meaning. The oddness of the event denoted by the verb is reflected in the speaker's reference to the reality created by Orwell. By doing so, the speaker suggests that under some special circumstances causing a person to fall sick is possible.

Alternatively, the data in (5), which come from a written text and employ quotation marks, can be interpreted as a citation of someone's utterance. Then, the speaker in (5) does not really refer to the actual act of causing a person to fall ill but rather to the words that could have been used by someone to describe the event. This interpretation highlights the value of what is said on the entity that is the addressee of the words. The act of saying or noting something is construed in (5) as affecting the entity coded as direct object. In effect, the interpretation imposed by the verb 
zachorowac ('fall sick') in the transitive construction involves the manipulation of facts by the government or media.

Apart from introducing the causer, the non-conventionalized uses of intransitive verbs in the transitive construction may additionally express some other elements of the transitive event, e.g. the instrument. This use is illustrated in (6) below, where the intransitive verb zachorować ('fall ill') is accompanied by direct object and instrument.

(6) Gdyby nie wyszło mieli zachorować

'If it did not work out they were supposed to fall-ill

pilota środkami przeczyszczającymi.,

pilot: ACC laxatives: INSTR

The clause in (6), in contrast to the one in (5), concerns the actual act of falling a person ill with the use of laxatives and construes the participant coded by the direct object as affected by the action of the externally introduced agent/causer.

The use of the transitive construction with change-of-state verbs significantly influences the interpretation of the roles of the participants in the event. The effect produced by such a creative use of the constructions is relatively strong. Firstly, an entity that is prototypically capable of inducing an action is construed as deprived of this ability and receives the coding of the direct object. Secondly, the action must be undertaken by some externally introduced participant who is portrayed as the one taking control and responsibility over the patient participant. Consider the example in (7), which was uttered by a speaker who takes care of a hadicapped person and helps her perform basic everyday activities.

\section{(7) Muszę wstać mamę.}

'I have-to stand-up mum: ACC'

The example very clearly illustrates how a person can be portrayed as deprived of the ability of standing up on her own and is forced to act in a certain way by an externally introduced agent/causer. The fact that a human is coded as a patient of an activity that she normally performs on her own imposes its construal as a passive victim treated like an inanimate entity. However, the use of an inherently intransitive verb in this context construes the agent/causer as being empathic with the patient, through whose perspective the situation is portrayed.

Such data illustrate the semantic import of introducing an agent/causer into a one-participant event prototypically coded by an inherently intransitive verb. The process of transitivization and at the same time causativization of a construction involves a shift in the interpretation of the participants. The entity undergoing an internally caused change of state, can be portrayed in the transitive construction as affected by the action induced by an external agent/causer. Therefore, the participants are assigned the features of the patient and agent, respectively. 


\section{Introducing the patient}

The data so far reflected how the conceptual structure of a one-participant event can be extended in order to include a layer of causation and, hence, introduce the agent/causer of the action. Thus, the transitivisation involved the introduction of a crucial element of the transitive scenario. However, a one-participant event can also be construed by the speaker as inherently transitive by incorporating an entity which gets affected as a result of the agent's action, i.e. the patient. This section presents a selection of data illustrating such a construal manipulation, by means of which an action that does not normally involve any object undergoing it, is portrayed as causing some effect on the patient. Consider one such example presented in (8) below.

(8) Wybuczeli powstańca warszawskiego Bartoszewskiego.

they-wy-hummed Warsaw insurgent: ACC Bartoszewski: ACC

'They hummed the Warsaw insurgent Bartoszewski out'

The verb employed in the example is prototypically intransitive and usually involves an agent who carries out the action designated by it. The action, however, fails to bring about any result or affect anybody or anything. The verb buczeć is used in a non-conventional way as it takes a perfectivizing prefix wy-, which imposes a perfective construal of the event. Moreover, the situation described in (8) implies that a prototypically intransitive action was performed in such a way or long enough to bring about some effect on an entity construed as the patient. The unusual character of the action is reflected in the choice of a non-schematic verb, which specifies how the action was performed. Some verbs of this kind are already conventionalized as transitive in Polish as in (9) below.

(9) (a) Wymamrotal tylko kilka stów. wy-murmur-past-3sg only a-few words: ACC 'He only murmured a few words.'

(c) Wygwizdali ja ze sceny. $w y$-whistle-past $-3^{\text {rd }} \mathrm{pl}$ her: ACC 'They whistled her out of the stage.'

(d) Wyśmiala go.

wy-laugh-past- ${ }^{\text {rd }}$ sg him: ACC

'She ridiculed him.'

The interpretation of the examples in (9) is deeply rooted in the characterization of prototypical resultatives as actions leading directly to some change (Nishimura, 1993). This description of agentive causation underlies the schematic semantic import of the coding in (8). The action denoted by the verb buczeć ('hum') does not 
normally imply the presence of a patient. In (8) it is used with a perfectivizing prefix $w y$ - and is followed by a direct object. This coding imposes a certain interpretation on the event, which is understood to be performed in such an unusual or extreme way as to affect some entity. Moreover, the verb does not lexically correspond to the meaning associated with the construction, but rather codes the means of achieving the act designated by the construction. In other words, humming is construed as the means of achieving caused-motion. Similarily, in example (10), stamping is what makes the patient change location.

(10) Biskupi wytupali raz abp. Gocłowskiego

bishops wy-stamped once archbishop: ACC Gocłowski: ACC

podczas obrad Episkopatu

during meeting episcopate: GEN

'Once the bishops stamped-out archbishop Gocłowski during the meeting of the Episcopate'

According to Talmy (1985), such non-canonical pairing of a verb and a construction is acceptable on condition that the action designated by the verb is a natural means of achieving the action specified by the construction.

The introduction of a patient into a one-participant event may involve different types of direct objects. Consider the example in (11).

(11) Posłowie oceniaja wypowiedź i moga go wyklaskać, wytupać

MPs evaluate speech and can him: ACC wy-clap wy-stamp

$i$ w ten sposób dać do zrozumienia, że nie zgadzają się z jego

and in this way let to understand that not agree-pres-3pl with his

opinia.

opinion

'The MPs evaluate the speech and can clap or stamp him out and, thus, let him know they disagree with him.'

Here, the patient is construed as affected by the action of the agent. However, the same verb can also be used in the transitive construction with the 'effected objects' as in (12) below.

(12) Tylko, że to jest ich własna, arbitralna decyzja. Nie możesz jej

only that it is their own arbitrary decision you cannot her: ACC

wytupać, wywrzeszczeć, wyawanturować, wymusić.

$w y$-stamp $\quad w y$-scream $w y$-quarrel $w y$-force

'But it is their own arbitrary decision. You cannot force it by stamping, screaming or arguing'

In the example above, the verbs additionally characterize the specific manner of performing the action, which accounts for their non-prototypical transitive use. In- 
terestingly, the data in (13), which involve a similar type of direct object, which is a product of the action denoted by the verb, rather than a patient affected by it. The example was used in reference to a book that was written on the basis of the story of a man who was completely paralysed after a stroke. The only means of communication he was able to resort to was his left eyelid, which he closed when a nurse was dictating alphabet. In this way, letter by letter, he managed to spell words and sentences.

(13) I tak, litera po literze, stowo po stowie, zdanie po zdaniu, and so letter after letter word after word sentence after sentence Bauby "wymrugal" "Motyla".

Bauby wy-winkedbutterfly

'And in this way, letter after letter, word after word, sentence after sentence, Bauby winked out "Butterfly".'

The non-prototypical use of the verb mrugać ('wink') with the perfectivizing prefix $w y$-is also motivated by the unusual character of the activity which leads to the creation of the entity coded as direct object.

In (14) is shown another instance of the cognate object construction.

(14) Chciałbym ci wykrzyczeć czasem moja radość, wytańczyć ją.

'I'd like to wy-scream my joy: ACC to you, wy-dance it: ACC

The transitive coding of an agent affecting his or her own emotions construes the situation as dynamic and energetic.

The transitive coding employing an inherently intransitive verb with a perfectivizing prefix and a direct object may also be applied metaphorically and/or metonymically, as in (15).

(15) Szacunek trzeba sobie wytupać.

respect: ACC need oneself $w y$-stamp

'You need to stamp your foot to gain respect'

The act of stamping is portrayed as a means of gaining respect. Thus, it stands for the type of behaviour that enables the agent to achieve some aim. On the other hand, the abstract object denoting a quality is understood in terms of a concrete object.

Novel examples employing the transitive coding with a perfectivizing prefix and an object are often formed on the basis of analogy as in (16).

(16) odklamać lata 80-te

$o d$-lie years: ACC 80: ACC

'delie the 80s' 
The verb is formed along the pattern which gives rise to numerous conventionalized verbs with the prefix $o d$-belonging to the category of reversative verbs, e.g. odkryć ('uncover'), odkopać ('dig out'). Hence, it is created as an opposition to the verb przekłamać ('falsify') and denotes the reversing of the action of lying about something.

The data above illustrate the use of the transitive construction in situations where the special character of the action performed by the agent is construed as bringing about affectedness on a participant which happens to take part in the event. Consequently, an inherently intransitive verb is used with a perfectivizing prefix and direct object which imposes a transitive interpretation of the event.

\section{Introducing a patient into one's sphere of control}

In the third type of non-canonical coding involving transitivity an entity may be construed as a patient and may be introduced into an event in which prototypically an agent performs an action on itself, i.e. a reflexive situation. Generally, reflexives profile a causal action in which a participant performs an action on itself and, thus, functions as both an agent and a patient. For this reason, it is encoded as the clausal subject and object at the same time. However, the reflexive clitic sie in Polish can be replaced with direct object, which involves the transitivization of the construction. Consequently, an action that is prototypically perfomed on oneself is construed as if it were affecting some other participant. Consider one such example in (17) which represents this type of coding.

(a) Wygląda na to, że próbujesz uśmiechnać go do zdjęcia.

'It looks as if you are trying to smile him: ACC to the photo'

(b) Teraz muszę jeszcze uśmiechnąć ich.

'Now I must smile them: ACC'

The verb uśmiechnać ('smile') is prototypically a reflexive verb used with the clitic sie, which is a detransitivizing device. In (17a) and (17b) it is employed with a nominal coded as direct object. The clause in (17a) was used as a comment on a photo in which a girl was touching boy's lips as if she was trying to shape them into a smile. The girl was forcing the boy to carry out an activity that one normally does on one's own. The effect produced by the coding involving a reflexive verb and direct object is that the person subject to the action is construed as being in the agent's sphere of control. By introducing an external causer/agent the patient is deprived of any potency and volitonality that he or she exhibits when performing the action in the normal course of events. In the example in (17b) the same verb was used by a child while painting in order to characterize the action of drawing smiles 
to the people in the picture. Being in control of his or her own work, the child can portray itself as the causer/agent who makes the figures smile.

The transitivization of reflexives is often employed to express actions which are performed on entities deprived of volitionality or will, such as children, handicapped people, or animals. Consider the examples in (18a) and (18b).

(a) I wyspać dziecko przed basenem, żeby nie marudzito, że jest zmęczone. "And $w y$-sleep child: ACC before the swimming-pool so that it does not grumble that it is tired.'

(b) przespacerować psa

prze-walk dog: ACC

'walk the dog'

The examples employ the prototypically reflexive verbs with the clitic sie replaced with direct object. The use of the transitive coding in such cases is well motivated as the construal emphasizes the patient-like nature of the object entity and at the same time the potency of the entity coded as agent who is in control of the action.

If the direct object participant is not constrained with regard to acting potency or handicapped, it can be construed as such, as in the example in (19), where it is deprived of volitionality and will. Prototypically the activity described in (19) is carried out by the agent on him- or herself but in the example below it is construed as caused by an external agent.

\section{(19) Wysiusiaj taksówkarza \\ wy-pee taxi-driver: ACC \\ 'Let a taxi driver use one's toilet'}

The expression in (19) characterizes a situation in which the agent allows the participant to use his or her bathroom. Interestingly, the agent does not actually perform the action designated by the verb, but rather allows the patient to perform it. Still, the volitionality and control that the former entity exerts over the action motivate the transitive construal and the assignment of the agent role to it.

Reflexive constructions in which the clitic is replaced with direct object nominal can also be found in child language. That is the case with example in (20) which is a title of a book for children. The occurence of this type of utterances may be due to the creative potential of children who have not yet mastered the distinctions between conventionalized reflexive and non-reflexive verbs. On the other hand, such novel uses illustrate the conceptual motivation based on the perceived similarity between the prototypical transitive scenario and the interpretation of a given event as transitive.

(20) Jak zakochatem Kaśkę Kwiatek.

'How I fell in love Kaśka: ACC Kwiatek' 
Prototypically, the action of falling in love is not instigated by an agent but rather experienced by a person. In (20) the agent/causer is construed as capable of making the participant coded as patient feel in a certain way. The clause has an inherently causative character, which at the same time produces a humorous effect, as, obviously, one cannot force another person to fall in love.

In brief, the replacement of the reflexive clitic sie with a direct object nominal is another transitivizing strategy by means of which an action prototypically performed by an agent on him- or herself is construed as affecting some other entity. This manipulation involves the introduction of an external agent/causer who is construed as the instigator of the action. In turn, the patient that is normally the only participant in the reflexive event gets into the agent/causer's sphere of control.

\section{Construing the event as more energetic}

The data presented so far constitute fairly marginal instances and are used only occasionally to construe a given situation in an innovative way and achieve certain semantico-pragmatic effects. Specifically, the manipulations of the transitive construal mostly involved a change in the interpretation of the participant entities. Now consider a set of data which also function as a variation in the coding of an event but, unlike the former examples, they are highly productive especially in colloquial Polish. An illustration of such structures given in the sentences in (21)-(23), which come from overheard conversations.

(21) Niech mu Pan walnie taki sam termin jak mnie.

hit him: DAT the-same deadline: ACC as me: DAT

'Give him the same deadline as you gave me.'

(22) Walniesz lufkę?

Will-you-hit barrel-DIM: ACC

'Will you have a shot (of vodka)?'

(23) Znowu walnąl ta sama gadkę/ten sam tekst

again he-hit the-same talk: ACC / text: ACC

'Again he gave me the same talk.'

The verb walnać ('hit') is employed here instead of the verbs dać ('give'), wypić ('drink), powiedzieć ('say'), respectively. It seems that it is common to replace some transitive verbs with a more schematic and at the same time more dynamic verb, by means of which the speaker imposes a more energetic and, therefore, more transitive construal of the situation. Consequently, the action characterized in this way gains dynamism which, in turn, livens up the utterance. Moreover, this shift in the por- 
trayal of the event involves a more agentive interpretation of the agent participant. The noticeable effect produced by this type of construal is that of expressing a more emotional attitude of the speaker in contrast to the use of less energetic verbs.

\section{Summary and concluding remarks}

The basic aim of the study was to provide a conceptually based account of a selection of non-conventionalized Polish data that constitute highly marginal members of the transitive category. In the course of the discussion of the novel data it was argued that a linguistic structure can be employed by the speaker in a nonconventionalized way in order to impose a chosen interpretation on the event and achieve certain rhetorical effect. In particular, the data illustrated how the creative application of the transitive construction serves the purpose of assigning certain features of the prototypical transitive event to a given situation. The conceptual analysis revealed that the two major aspects of the transitive construal that are imposed on the data involve the elaboration of the action chain with regard to the introduction of the agent or the introduction of the patient.

An interesting observation concerning the two most prominent parameters with regard to which the novel uses of constructions are employed, i.e. agency/causation and patient affectedness, was made by Lyons, who argues:

The fact that there are so many transitive verbs with the same valency as kill, not only in English and the Indo-European languages, but possibly in all languages, would suggest that, as human beings, we are particularily interested in the results of our purposive actions and the effects that our actions have upon patients

(Lyons, 1977: 491)

The claim made by Lyons quite convincingly explains the development of the transitive category as it points to the significance of canonical transitivity in our conceptual and, thus, also linguistic activity.

Last, but not least, it should be emphasized that the choice of creative uses of language as evidence in the analysis is well motivated. First of all, nonconventionalized expressions reveal some subtle semantic aspects of the grammatical category to which they belong. In great majority the presented examples fail to have a conventionalized counterpart but can only be paraphrased, e.g. with the causative construction (e.g. zachorować kogoś vs. sprawić, żeby ktoś zachorowat 'to fallill someone; vs. 'to make someone fall ill'). Thus, it can be argued that the novel uses of verbs in the transitive construction often fill some semantic gaps. Moreover, the motivation for the use of creative expressions arises from their ability to attract the hearer's attention. 
To conclude, the data presented clearly illustrate the understanding of transitivity as a construal phenomenon that plays a major role in portraying a situation in a particular way. The vital function of transitivity in construing a scene is clearly indicated by Rice, who draws the following conclusion:

[Transitivity] is built up anew each time the speaker surveys a scene and wishes to encode the event in linguistic form. If an event is interpreted as consisting of certain properties or if the speaker wants to bias his listener's interpretation of an event in a certain way, he may choose particular lexical items and arrange them in such a fashion as to create a clause that a linguist considers to be transitive based on its passivizability. At the very least, facets of the prototype are distributed over the elements of the clause. Probably, however, it is more accurate to say that transitivity is distributed over the entire speech act, by which I mean that the speaker has control over how the event is to be interpreted by the way in which he formulates the corresponding clause.

(Rice, 1987: 261)

The study offered here is deeply rooted in this view of transitivity and applying the conceptual tools to language analysis provides a cognitive account of the phenomenon.

\section{Bibliography}

Langacker, R.W. 1991. Foundations of Cognitive Grammar. Vol. 2: Descriptive Application. Stanford: Stanford University Press.

Lyons, J. 1977. Semantics. Vol. 2. Cambridge: Cambridge University Press.

McKoon, G. and T. Macfarland. 2000. "Externally and internally caused change of state verbs". Language 76. 833-858.

Nishimura, Y. 1993. "Agentivity in cognitve grammar". In: Geiger, R.A. and B. Rudzka-Ostyn. (eds.). Conceptualization and mental processing in language. Berlin: Mouton de Gruyter. 487-530.

Rice, S. 1987. "Towards a cognitive model of transitivity". Unpublished doctoral dissertation. San Diego: University of California at San Diego.

Rudnicka, K. 2009. "Transitivity as a construal phenomemon. A cognitive study". Unpublished doctoral dissertation. Warsaw: Uniwersytet Warszawski.

Smith, C.S. 1970. "Jespersen's 'move and change' class and causative verbs in English". In: Mohammad Ali, J., Polome, E.C. and W. Winter. (eds.). Linguistic and literary studies in honor of Archibald A. Hill. Vol. 2: Descriptive linguistics. The Hague: Mouton. 101-109.

Talmy, L. 1985. "Lexicalization patterns: semantic structure in lexical forms". In: Shopen, T. (ed.) Language typology and syntactic description. Vol 3: Grammatical categories and lexicon. Cambridge: Cambridge University Press. 57-149. 
